e-Neuroforum 2015 - 6:57

DOI 10.1007/s13295-015-0008-9

Published online: 16 July 2015

(c) Springer-Verlag Berlin Heidelberg 2015
Jochen F. Staiger ${ }^{1,2} \cdot$ Martin Möck $^{2} \cdot$ Alvar Proenneke $^{2} \cdot$ Mirko Witte $^{2}$

${ }^{1}$ Center for Anatomy, Institute for Neuroanatomy, University Medical Center Göttingen, Göttingen, Germany

${ }^{2}$ Institute for Neuroanatomy, University Medical Center, Georg-August-University, Göttingen, Germany

\title{
Erratum to: What types of neocortical GABAergic neurons do really exist?
}

Erratum to:

e-Neuroforum (2015).

DOI 10.1007/s13295-015-0006-y

Please note that after online publication of this article, Fig. 1 and Fig. 2 were updated.

\section{Corresponding address}

\section{Prof. Dr. J. F. Staiger}

Center for Anatomy, Institute for Neuroanatomy

University Medical Center Göttingen

Kreuzbergring 36, 37075 Göttingen

jochen.staiger@med.uni-goettingen.de 